\title{
Financial Literacy on Impulsive Buying Behavior in Y Generation
}

\author{
Nur Aini Anisa ${ }^{\mathrm{a}}{ }^{*}$, Syamsul Arifin ${ }^{\mathrm{b}}$, Lis Setyowati ${ }^{\mathrm{c}}$, Nur Hidayah ${ }^{\mathrm{d}}$, Aisyah Darti Megasari ${ }^{\mathrm{e}}$ \\ ${ }^{a}$ Sekolah Tinggi Ilmu Ekonomi Pemuda Surabaya, Surabaya, Indonesia, nurainianisa.stiepemuda@ gmail.com \\ ${ }^{b}$ Sekolah Tinggi Ilmu Ekonomi Pemuda Surabaya, Surabaya, Indonesia, syamsularifin.stiepemuda@gmail.com \\ 'Sekolah Tinggi Ilmu Ekonomi Pemuda Surabaya, Surabaya, Indonesia, issetyowati.stiepemuda@gmail.com \\ ${ }^{d}$ Sekolah Tinggi Ilmu Ekonomi Pemuda Surabaya, Surabaya, Indonesia,nurhidayah.stiepemuda@gmail.com \\ ${ }^{e}$ Sekolah Tinggi Ilmu Ekonomi Pemuda Surabaya, Surabaya, Indonesia, aisyahdarti.stiepemuda@gmail.com
}

\begin{abstract}
Impulse buying is a phenomenon that can occur in all generations but more done by the generation that undergoes a change that is the age of adolescents who step on the early adulthood of the Y generation who actually do not have the financial ability to meet their needs. This study aims to analyze the influence of financial literacy on the impulsive buying behavior of online products in $\mathrm{Y}$ generation. This research is a descriptive research type, with a quantitative approach. The population of 733 students. The sampling technique used in this research is nonprobability sampling by using purposive sampling type with sample of 142 students. The subject of this research is the students of university. Data collection technique using questionnaire. Data were analyzed using linear regression analysis. The result of data analysis shows that there is influence of financial literacy on impulse buying behavior of online product in $\mathrm{Y}$ generation. It means the higher the student's financial literacy, the lower the impulse buying behavior. Conversely, the lower the student's financial literacy, the higher the impulse buying behavior. Data were analyzed using linear regression analysis. The result of data analysis shows that financial literacy has negative effect, but significant to impulsive buying behavior of online product in Y generation. It means The higher student's financial literacy, the lower impulse buying behavior. Conversely, the lower student's financial literacy, the higher impulse buying behavior.
\end{abstract}

Keywords: Impulsive Buying, Financial Literacy, Y Generation

\section{Introduction}

The development of internet technology has given birth to a generation that has different behaviors compared to previous generations. Generation $\mathrm{Y}$ who were born in the internet era is considered complete the previous generation of the baby boomers and generation X. The availability of various information media in the lives of generation Y provides a significant impact on the behavior of search information in making purchasing decision (Suryani, 2013). Generation Y gets a lot of ease in making purchasing decisions. Generation is a strong determinant of online buying behavior. It has been proven in research that has found that Generation Y contributed to the highest percentage of online purchases, followed by Generation X and Baby Boomers. According to Lachman and Brett (2013), Generation Y takes seriously spending and spends a lot of time online including researching, fantasizing, recalling promotional sales, checking out what celebrities are wearing and then imagining how they will look with the same outfit.

Generation Y has developed different shopping styles compared to previous generations (Bakewell and Mitchell, 2003). Generation $Y$ is socialized in a materialistic society (Bakewell et al., 2006) and has a wide social network (Parment, 2009). This will have an impact on consumer behavior in the generation $\mathrm{Y}$ that is students born in the years 1980 to 1999 (Gurau,2012) in which the student tendency in consumptive is very high.

Various factors namely internal and external factors that give rise to this consumptive nature. The existence of consumptive nature of Generation $\mathrm{Y}$ makes purchases more frequent and more impulsive than Generation $\mathrm{X}$ consumers (Ofrit and Lissitsa, 2016).This impulsive buying is an unplanned buying that where it happens all of a sudden.

\footnotetext{
* Corresponding author.

E-mail address: nurainianisa.stiepemuda@gmail.com (Nur Aini Anisa)
} 
Impulsive purchase is a psycho-economical phenomenon that afflicting many people's lives. In an impulsive buying process, a potential buyer leads directly to a particular product and then makes purchase quickly. The behavior of impulsive buying unconsciously when individuals engage in activities related to money and life styles. Impulsive buying is a phenomenon that can occur in all generations but more done by the generation that experienced a change that is the age of adolescents who stepped on early adulthood who actually do not have the financial ability to meet their needs.

According to Mowen and Minor (2002: 10) impulsive buying is the act of buying that was not previously recognized consciously as a result of a consideration or the intention to purchase that are formed before. Impulsive buying or spontaneous unplanned purchases is related to individual nature of the excessive consumption so that the urge to buy suddenly at a time when consumers browse the online shop. Verhagen and Dolen (2011) shows that impulsive buying occurred around $40 \%$ of all online spending. This tren is the result of easy access to the product, easy purchase, lack of social pressure.

Impulsive buying will not occur if the generation of $\mathrm{Y}$ understands about the income they have. Given that the majority of $\mathrm{Y}$ generation still earn income from parents, it should be planned in advance in making a purchase that is see the needs not desire. This is related to financial literacy that should be known and understood by each individual of generation Y. Financial literacy is skills (literacy) is an important must-have for achieving its goals. Understanding the financial implications generated from financial decisions are fundamental to financial literacy.

Luzardi et al. (2011) states that financial literacy is a person's ability to process economic information to make decisions about financial plans, accumulation of wealth, debt and pension. Financial literacy is an individual understanding of the financial plan in which the goal can make financial decisions in accordance with the plan. This is based on the research of Robin and Lynda (2010) that the participants in the study who have poor financial management practices is more likely to be impulsive buyers. The financial literacy that should be owned in the process before deciding the purchase of how to manage good finances, how to create a budget in a need and how financial planning that suits the needs. In addition, in line with research from Shahnaz and Moeinadin (2015) from the results of study suggest that on financial literacy that people with low financial literacy are more vulnerable to impulse buying. So it can be stated that the financial literacy becomes must be mastered by every individual, especially students in Y generation that aged between 19-21 years old in which students is easy to be influenced in making buying decisions at that time.

Based on the background of the problem, then the research problems in this study namely, are there influences of financial literacy on impulsive buying behavior of online products in $\mathrm{Y}$ generation.

\section{Review of related literature}

\subsection{Financial Literacy}

Huston (2010) states that financial knowledge is an inseparable dimension of financial literacy, but can not yet describe financial literacy. Orton (2007) clarified by stating that financial literacy is an integral part of one's life because financial literacy is a useful tool for making informed financial decisions, but from experience in various countries still shows relatively less.

Byrne (2007) also found that low financial knowledge will lead to faulty of financial planning, and cause bias in achieving prosperity at a time when the age is no longer productive. "Financial literacy is the knowledge to manage finances in financial decision making (Chen and Volpe 1998).

Cude (2006) defines financial literacy as the ability to read, analyze, manage, and communicate about personal financial conditions that affect the material welfare. This includes the ability to distinguishes financial options, 
discuss money and financial problems, plan for the future, and respond competently events that affect everyday financial decisions, including those that occur in the economy in general.

Based on some opinions according to the expert that financial literacy is the knowledge, abilities and skills owned by someone in managing the finances which can be used to make an effective financial options. As for the financial knowledge that must be owned by students that is basic knowledge of personal finance, knowledge of money management, budgeting, saving, in which in every aspect can create knowledge of each student in decision making. The financial literacy capacity that is owned by a person will be the creation of material welfare.

\subsection{Impulsive Buying}

Impulsive buying are when a consumer all of sudden having impulse that he cannot avoid (Solomon, 2009). Verplanken and Herabadi (2001) define impulsive buying as irrational buying associated with quick and unplanned buying, followed by emotional conflicts and emotional impulses.

Engel,et all (2006) suggest five important characteristics that distinguish impulsive and non-impulsive consumer behavior. These characteristics are: spontanity, power, compulsion and intensity, excitement and stimulation, disregard for consequence.

\section{Methodology}

According to the type of data collected, this study is included in the type of quantitative research. In this study, taken as a population is a student in university which entered the Y generation of aged 19-21 years who have made buying that was not planned or so-called with impulsive purchases on fashion online products. The number of population in the research is as much as $733 \mathrm{Y}$ generation. Sampling is done using purposive sampling based on several criteria so that the number of sample as much as 142 .

This research are conducted distributing questionnaires that contains questions and statements regarding consumer behavior in online buying impulsively on fashion products. Distribution of questionnaires conducted by asking first whether the students had ever made online buying impulsively on fashion products. If the student ever make online buying impulsively then the student chose as respondent and went on to complete a questionnaire.

\section{Result and discussion}

\subsection{Research result}

Data analysis was done with the aim of simplifying the data into a form that is easier to read and interpreted, which in this process is often used statistics because the statistics have a function in simplifying the data. In this study the data analysis techniques used is Linear Regression Analysis with the help of SPSS program version 16 with results as in table 1.

Based on Table 1 it can be seen that the value of regression coefficient variable of financial literacy $\left(\mathrm{X}_{1}\right)$ that is amounted to -0.321 with a negative sign indicated that there was a negative and significant financial literacy on impulsive buying behavior. The higher student's financial literacy, The lower impulsive buying behavior was done.

Table 1 Linear Regression Test Result 


\begin{tabular}{|c|c|c|c|c|}
\hline \multirow[t]{2}{*}{ Variable } & \multicolumn{2}{|c|}{$\begin{array}{l}\text { Unstandardized } \\
\text { Coefficients }\end{array}$} & \multirow[t]{2}{*}{$\mathbf{T}$} & \multirow[t]{2}{*}{ Sig } \\
\hline & B & Std.Error & & \\
\hline Constants & 1.728 & 0.325 & 5.319 & $<0.001$ \\
\hline Financial Literacy (X1) & -0.326 & 0.150 & -2.179 & 0.031 \\
\hline
\end{tabular}

Source: Data ptocessed by researches

\subsection{Discussion}

Financial literacy or financial literacy is an important factor for everyone in managing their personal finances. A person's ability to read, analyze and manage financial conditions when making a financial decision to avoid financial problems. Individuals must have a knowledge and skills to manage their personal financial resources effectively for their welfare. Similarly with the students. Students belonging to the Y generation have different characteristics than the previous generation in terms of buying decision. So it is very necessary for financial literacy in the students in making unexpected or impulsive buying. Given that the consumer's consumptive nature of Y generation is very high.

According to Orton (2007) clearly that financial literacy became inseparable in one's life because financial literacy isa useful tool for making informed financial decisions, but from experience in various countries still shows relatively less high. Financial literacy is the knowledge to manage finances in financial decision making (Chen and Volpe 1998).

This research suspect that financial literacy affect significantly on impulsive buying behavior of online product Y generation is proven to be. Based on the results of the analysis showed that financial literacy affected negative and significant on impulsive buying behavior of online product in $\mathrm{Y}$ generation in which if the student has a low financial literacy or skills in managing low-income, then students will perform a high impulsive buying behavior. Conversely that if the student understands the financial literacy then impulsive buying behavior will be low.

The results of this study is similar with the study by Robin and Lynda (2010) stated that materialistic individual and have poor financial management practices is more likely to be impulsive buyers. This is due to lack of understanding in doing budgeting in its own finances. In addition, in line with the study of Shahnaz and Moeinadin (2015). From the results of the study suggested that regarding financial literacy that people with low financial literacy are more vulnerable to impulse buying.

So it can be stated that the financial literacy becomes must be mastered by every individual, especially students in $\mathrm{Y}$ generation which aged19-21 years old in which students is easy to be influenced in making buying decisions at that time. This is supported by findings in the field that students with basic knowledge of poor personal finance tend not to think of buying decisions that fit their needs. In addition, with knowledge on poor financial management, students tend to be unable to manage their own finances. Findings about budgeting and saving students tend not to be able to budget the money to be spent and save money for the next needs.

\section{Conclusion and suggestion}

\subsection{Conclusion}

Financial Literacy affect on impulsive buying behavior of online products in Y generation. Financial literacy partially affect negative and significant on the behavior of impulsive buying of online products in Y generaton. This is proven that the higher the financial literacy of students, then the lower the impulsive buying behavior. In contrast, the lower the financial literacy of the students, then the higher the impulsive buying behavior. The findings of this study are more dominantly supported by indicators of knowledge about money management. This can be shown from 
the findings that most students do not understand the knowledge of their own financial management, resulting in unplanned decision making buying or impulsive buying.

\subsection{Suggestion}

Based on the findings which prove that financial literacy has negative effect, but significant to the impulsive buying behavvior of online products in $\mathrm{Y}$ generation with knowledge on money management as an indicator of the most dominant in support of an impulsive buying, so that an impulsive buying does not occur or minimize the customs of impulsive buying done by the students. Then students should understand more about managing their own money which can be done by elaborate any needs and budget before deciding to buy the product.

\section{References}

Atefeh, Shahnaz dan Mahmoud. 2015. The Effect of Education and Financial Commitments on the Lack of Programming in Purchase (Case Study: Accounting graduate students of Islamic Azad University, Yazd). Research Journal Of Fisheries And Hydrobiology, 10(10) June 2015, Pages: 622-629.

Beatty, S. E. and Ferrell, M.E. 1998. Impulse buying: Modeling its precursors, Journal of Retailing, 74, 169-191.

Byrne, A. 2007. Employee saving and investment decisions in defined contribution pension plans: survey evidence from the U.K. Financial Services Review 16 (2007) 19-40.

Cathy Bakewell, Morgan Rothwell, Vincent Wayne Mitchell, P.2006. "UK Generation Y Male Fashion Consciousness" Journal Fashion Marketing and Management, Vol. 10, No.2.

Cathy Bakewell, Vincent Wayne Mitchell, P. 2003. "Generation Y Female Consumer Decision Making Style" International Journal of Retail \& Distribution Management, Vol. 31, No.2.

Chen, H. \& Volpe, R. 1998. An Analysis of Personal Financial Literacy Among College Students, Financial Services Review, Vol. 7 No.2, pp. 107-128

Cude, B., et al. 2006. College Students and Financial Literacy: What They Know and What We Need to Learn. Proceedings of the Eastern Family Economics and Resource Management Association, Eastern FamilyEconomics and Resource Management Association, pp. 102-109.

Engel, J.F, Blackwell, R.D., and Miniard, P.W.2006.Consumer behavior $\left(10^{\text {th }}\right.$ ed).Mason: Thomson South-Western.

Gurau, C. 2012. A life-stage analysis of consumer loyalty profile: comparing Generation X and Millennial consumers. Journal of Consumer Marketing,29 (2):103-113.

Huston, S.J. 2010. Measuring financial literacy. Journal of Consumer Affairs Volume 44 Issue 2.

Kol, Ofrit and Lissita, Sabina. 2016. Generation X Vs Generation Y- A decade of online shopping. Journal or retailing and consumer service 31.304-312.

Lachman, M. L., \& Brett, D. L. 2013. Generation Y: Shopping and Entertainment in the digital age.

Lusardi, A., Mitcherll. O., S. 2011. Financial Literacy around the World: an Overview. NBER Working Paper Series. Working Paper 17107.

Mowen, John C. dan Michael Minor. 2002. Consumer Behaviour. Diterjemahkan oleh Lina Salim. Edisi Kelima, jilid 1 dan 2. PT. Penerbit Erlangga. Jakarta

Orton, L. 2007. Financial Literacy: Lesson From International Experience. CPRN Research Report, September 2007, pp. 1-63.

Parment, Anders. 2013. Generation Y Vs Baby Boomers: Shopping behavior, Buyer Involvement and Implications for Retailing. Journal of Retailing and Consumer Services 20 189-199.

Pentecost, Robin and Andrews, Lynda .2010. Fashion retiling and the bottom line: The effect ofgenerational cohorts, gender, fashion fanship, attitudes, and impulse buying on fashion expenditure. Journal of Retailing and Consumer Service 43-52. 
Remund, D. L. 2010. Financial literacy explicated: The case for a clear definition in an increasingly complex economy. The Journal of ConsumerAffairs, 44(2), 276-295

Solomon, M.R. 2009.Consumer behavior: buying, having, and being (8th ed). Upper Saddle River, New Jersey: Prentice-Hall.

Suryani, Tatik. 2013. Perilaku Konsumen Di Era Internet. Yogyakarta: Graha Ilmu. Verplanken, B. \& Herabadi, A. 2001. Individual Differences in Impulse Buying Tendency: Feeling and no Thinking. European Journal of Personality.15, S71-S83.

Verhagen, T., \& Dolen, V. W. 2011.“The Influence of online Store Beliefs on Consumers Online Impulse Buying: A Model and Empirical Application,” Journal Information \& Managemen, Vol. 48, pp. 320-327. 